\title{
In Vitro Propagation and Ex Vitro Establishment of a Medicinal Plant- Gynura procumbens (Lour.) Merr. through Leaf Culture
}

\author{
Mustafa Abul Kalam Azad, Muhammad Nurul Amin \\ Department of Botany, University of Rajshahi, Rajshahi 6205, Bangladesh.
}

*Corresponding Author: Dr. Mustafa Abul Kalam Azad, Associate Professor, Department of Botany, University of Rajshahi, Rajshahi 6205, Bangladesh.E-mail: drmakazad@gmail.com

\begin{abstract}
An effective protocol for adventitious shoot proliferation was established on MS medium supplemented with different concentrations of cytokinin and auxin using leaf explants from in vitro grown shoots of Gynura porcambens. Highest frequency $86.67 \%$ of adventitious shoot formation, maximum number 20.52 of shoots per explant and average $7.3 \mathrm{~cm}$ length of shoot were obtained on MS medium supplemented with $4.0 \mu$ M 6-Benzylaminopurine (BAP) and 1-Naphthaleneacetic acid (NAA). Shoot multiplication and growth were significantly affected by different types of basal medium, level of concentration of sucrose, and pH. The highest rate (92.31\%) of shoot production was achieved in a shoot-regenerating full strength of MS basal medium with $30 \mathrm{gm} / \mathrm{l}$ sucrose where $\mathrm{pH}$ was adjusted to 6.0. For rooting, the in vitro proliferated and elongated shoots were excised into 2-4 cm long microcuttings, which were planted individually on a rootinduction MS medium containing $4.0 \mu \mathrm{M}$ Indole-3-butyric acid (IBA). Within 4 weeks of transfer to the rooting medium, all the cultured microcuttings produced 2-6 roots. The in vitro regenerated plantlets were transferred to vermicompost, and the survival rate underex vitro was $100.00 \%$.
\end{abstract}

Keywords: Medicinal Plant, Adventitious Shoot Regeneration, Culture Medium, Plant Growth Regulators, Vermicompost.

\section{INTRODUCTION}

Gynura procumbens Merr. belonging to the family Asteraceae is a medicinal plant commonly found in tropical Asia countries such as China, Thailand, Indonesia, Malaysia, and Vietnam. Traditionally, it is widely used in many different countries for the treatment of a wide variety of health ailments such as kidney discomfort, rheumatism, diabetes mellitus, constipation, and hypertension. Based on the traditional uses of $G$. procumbens, it seems to possess high therapeutic potential for treatment of various diseases making it a target for pharmacological studies aiming to validate and provide scientific evidence for the traditional claims of its efficacy. G. procumbens have been long used as ethnoherbal products to treat various ailments such as diabetes, hypertension, urinary infection and used as anti-inflammatory and anti-allergic agents (Jiratchariyakul et al., 2000). However its phytochemical properties have not been well studied until recently. Bohari et al. (2006) reported the extracts of this plant had an enhancing effect on glucose uptake in 3T3 adipocyte cell lines and they suggested that the anti-diabetic action of $G$. procumbens might be mediated through the stimulation of glucose uptake. Iskander et al. (2004) discovered that the crude ethanolic extracts of $G$. procumbens showed anti- inflammatory properties and steroid might be one class of antiinflammatory compounds found in this plant. Zhang and Tan (2000) reported that the leaves extracts of $G$. procumbens had significantly suppressed the elevated serum glucose levels and reduced the serum cholesterol and triglyceride levels in diabetic rats. Akowuah et al. (2001) discovered that the nbutanol extracts of this plant could reduce the blood glucose levels in streptozotocin-induced type 2 diabetic rats. Two compounds, 3, 5-di-O-caffeoylquinic acid and 4, 5-di-O-caffeoylquinic acid, identified from this plant were found to inhibit the replication of viruses (Jiratchariyakul et al., 2000).

G. procumbens is commonly used for diabetes treatment in traditional medicine and its hypoglycemic effect has been reported in in vivo studies (Hamid et al., 2004; Algariri et al., 2014). One intriguing finding on $G$. procumbens, is its specificity in inducing hypoglycemic effect only in diabetic animals as it has been shown to cause a significant decrease in fasting blood glucose levels and suppression of glucose elevation during glucose tolerance test in diabetic rats but not normal rats (Algariri et al., 
2014).The effect of G. procumbens treatment on insulin level has been investigated. Hamid et al. (2004) has reported the stimulation of insulin secreting cell lines by G. procumbens extract. However, the exposure of clonal pancreatic cells with extract of $G$. procumbens did not stimulate insulin secretion (Hassan et al., 2010). These contradicting results might be due to the differing response of different cell lines when treated with $G$. procumbens. Therefore, its effect on insulin secretion has been further tested using in vivo studies. However, no significant change has been observed in plasma insulin level in diabetic rats treated with the extracts, implying that the hypoglycemic activity of $G$. procumbens does not rely on insulinotropic activity but may instead be due to its extra-pancreatic effect (Hassan et al., 2010; Lee et al., 2012).

This plant is conventionally propagated by cuttings. The conventional method cannot meet the increasing demandof this plant used as the raw material for the preparation of pharmaceutical, dermaceutical and aromatherapeutical products. The in vitro culture techniques can be the alternative for the continuous provision of plantlet stocks for large scale field cultivation. By considering the medicinal value and antidiabetic properties of G. procumbens was undertaken for develop a suitable micropropagation protocol for the mass production of this plant species. Here, we established an efficient protocol which can be used at a large scale for the clonal multiplication of this plant species using leaf as explants derived from the in vitro grown shoots. To our knowledge, there are few reports on axillary shoot proliferation but there are no report on adventitious shoot regeneration of this plant species.

\section{Materials AND Methods}

\section{Plant material and culture medium}

Leaf explants of Gynura procambens were collected from in vitro grown shoots, were cut small pieces, and were placed in $250 \mathrm{ml}$ conical flask containing 2.0-6.0 $\mu \mathrm{M}$ BAP in combination with 1.0$2.0 \mu \mathrm{M}$ NAA or IBA supplemented MS (Murashige and Skoog, 1962) medium prepared with 3\% $(\mathrm{w} / \mathrm{v})$ sucrose and $0.8 \%(\mathrm{w} / \mathrm{v})$ agar (Sigma Chemical Co. USA). The $\mathrm{pH}$ of the medium was adjusted to $5.7 \pm 1$ before autoclaving at $121^{\circ} \mathrm{C}$ for 20 minutes at $1.2 \mathrm{~kg} / \mathrm{cm}^{2}$ pressure.

\section{Shoot induction and proliferation}

To find out the suitable basal medium for adventitious shoot regeneration from leaf explants were initially cultured on four different basal medium viz. MS (Full strength of MS medium), 1/2MS (Half strength of MS medium), 1/4MS (Quarter strength of MS medium) and B5 (Gamborg et al., 1968) medium supplemented with $4.0 \mu \mathrm{M}$ BAP with $2.0 \mu \mathrm{M}$ NAA.

Leaf explants were also used for examining the effects of sucrose concentrations on shoot regeneration. Six different concertation $(15.0,20.0,25.0,30.0,35.0$ and $40.0 \mathrm{gm} / \mathrm{l})$ of sucrose in a medium were employed for the experiments. In addition to test the effects of $\mathrm{pH}$ on adventitious shoot regeneration from leaf explants of in vitro grown shoot were cultured on MS medium containing 4.0 $\mu \mathrm{M}$ BAP in combination of $2.0 \mu \mathrm{M}$ NAA where $\mathrm{pH}$ level of culture medium were adjusted to 5.0, 5.5, 6.0 and 6.5 .

\section{Formation of adventitious root, hardening and acclimatization}

Microshoots of 1-3 cm length were prepared from usable shoots by snipping off the basal leaves and cultured them individually in $25 \times 150 \mathrm{~mm}$ culture tubes with $10-15 \mathrm{ml}$ of full strength MS medium supplemented with 2.0-6.0 $\mu \mathrm{M}$ of IBA, NAA, or IAA (Indole-3-acetic Acid). Rooted plantlets were transferred on to the small plastic pots containing sterilized soil mix (garden soil: sand: compost in 2:1:1 ratio) and vermicompost, separately. Transferred plantlets were hardened in growth chamber condition for 20 days and then transferred to outdoor condition. The total number of plants transferred to the pots and the number of surviving plants in the outdoor condition were recorded. All the cultures were maintained at $25 \pm 1{ }^{\circ} \mathrm{C}$ under a 16h light and $8 \mathrm{~h}$ dark cycle with the light intensity of 2000-3000 lux provided by cool-white fluorescent tubes.

\section{Statistical analysis}

Data were recorded after 8 weeks of culture except for rooting experiment when the data were recorded after 4 weeks of incubation. In all the experiments, 12-15 explants were used and each experiment was repeated three times. Mean and standard error were calculated for all numerical data. The mean data of each treatment were compared by using Duncan's Multiple Range Test (DMRT) at $\mathrm{P}=0.05 \%$. 
In Vitro Propagation and Ex Vitro Establishment of a Medicinal Plant- Gynura procumbens (Lour.) Merr. through Leaf Culture

\section{RESULT AND DISCUSSION}

\section{Shoot Regeneration}

Most of the leaf explants of G. porcambens elongated within 20 days of incubation. Direct shoot regeneration was observed after 5 weeks of culture incubation. Adventitious shoot proliferation occurred from the cut margin of the leaf explants. Figure 1 shows the percentage of explants that responded formation of shoots, average number of shoots, and average length of shoots per explant. Most of the media induced shoot proliferation through direct organogenesis, and the primordia always regenerated directly from the leaf without forming callus (Fig.2A). The range of the percentage of shoot regenerating explants was $86.67 \pm 2.5$ to $64.29 \pm 1.7 \%$. The data showed significant differences $(\mathrm{p}<0.05)$ among the various hormonal treated culture media. In this experiment the maximum percentage $(86.67 \pm 2.5 \%)$ of shoot regenerating explants was observed on MS medium with $4.0 \mu \mathrm{M}$ $\mathrm{BAP}$ and $2.0 \mu \mathrm{M}$ NAA, which also induced the average highest total number $(20.52 \pm 0.8)$ of shoots and the average highest length $(7.3 \pm 0.5 \mathrm{~cm})$ of shoots (Fig. 2B-C). Similar result was found in Alstroemeria (Lin et al., 1997), Phellodendron amurense (Azad et al., 2005), Torenia fournieri (Kanchanapoom et al., 2009), Plectranthus barbatus (Thangavel et al., 2011). Among the BAP-IBA combinations, the maximum frequency $(78.57 \pm 2.2 \%)$ of shoot bud formation and total number $(16.31 \pm 1.1)$ of shoot per explant were obtained at $4.0 \mu \mathrm{M}$ BAP with $2.0 \mu \mathrm{M}$ IBA. The results obtained in the present study are in agreement with this regarding Malus hupehensis var. pinyiensis (Wanmeiet al., 2014). Among different growth regulator supplements, NAA seems to be more effective in shoot differentiation than IBA. High concentrations of cytokinin and auxin in the medium inhibited shoot formation.

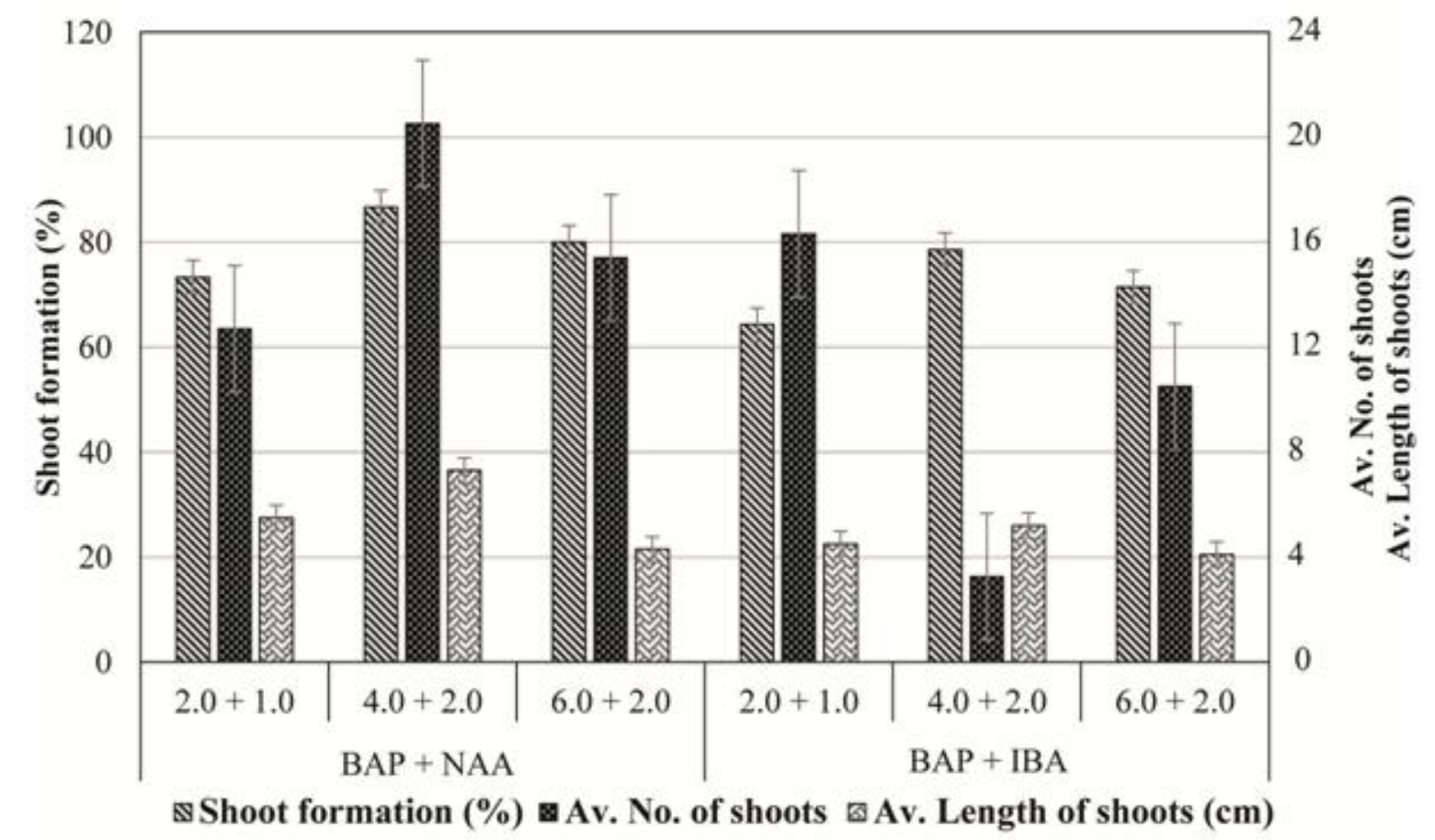

Figure 1. Effects of explants on MS medium containing different concentrations of auxins and cytokinin on axillary shoot proliferation of Gynura procumbens.

\section{Effects of Medium}

The leaf explants significantly affected shoot proliferation on full strength MS medium supplement with $4.0 \mu \mathrm{M}$ BAP with $2.0 \mu \mathrm{M}$ NAA than other three media (1/2MS, 1/4MS and B5) tested (Fig. 3). Maximum $85.71 \pm 1.31 \%$ explants produced highest $22.2 \pm 0.21$ shoots with highest average length $7.2 \pm 0.11 \mathrm{~cm}$ on MS medium. The second highest frequency $76.92 \%$ of shoot proliferation $12.5 \pm$ 0.21 average number of shoot and $5.5 \pm 0.52 \mathrm{~cm}$ length of shoot were obtained on $1 / 2 \mathrm{MS}$ medium. Considerable shoot proliferation were observed on B5 medium. The lowest performance of shoot proliferation, number of shoot, and shoot length were found on $1 / 4 \mathrm{MS}$ medium. This study revealed that full strength MS medium was preferred for adventitious shoot proliferation from leaf explants of 
G. procambens while B5 medium showed a little effect in terms of shoot proliferation. Full strength MS medium has been proved best for adventitious shoot proliferation in many other medicinal species, such as Malus hupehensis var. pinyiensis(Jin et al., 2014), Hygrophila polysperma (Karatas et al., 2013), Plectranthus barbatus (Thangavel et al., 2011), Lilium (Bacchetta et al., 2003), and Adhatoda vasica (Azad et al., 2003). Similar results were also observed in some other woody trees, like Phellodendron amurense (Azad et al., 2004), Accia catechu (Kaur et al., 1998), Accia nilotica (Abbas et al., 2010), and Colutea istria (Hegazi and Gabr, 2010).

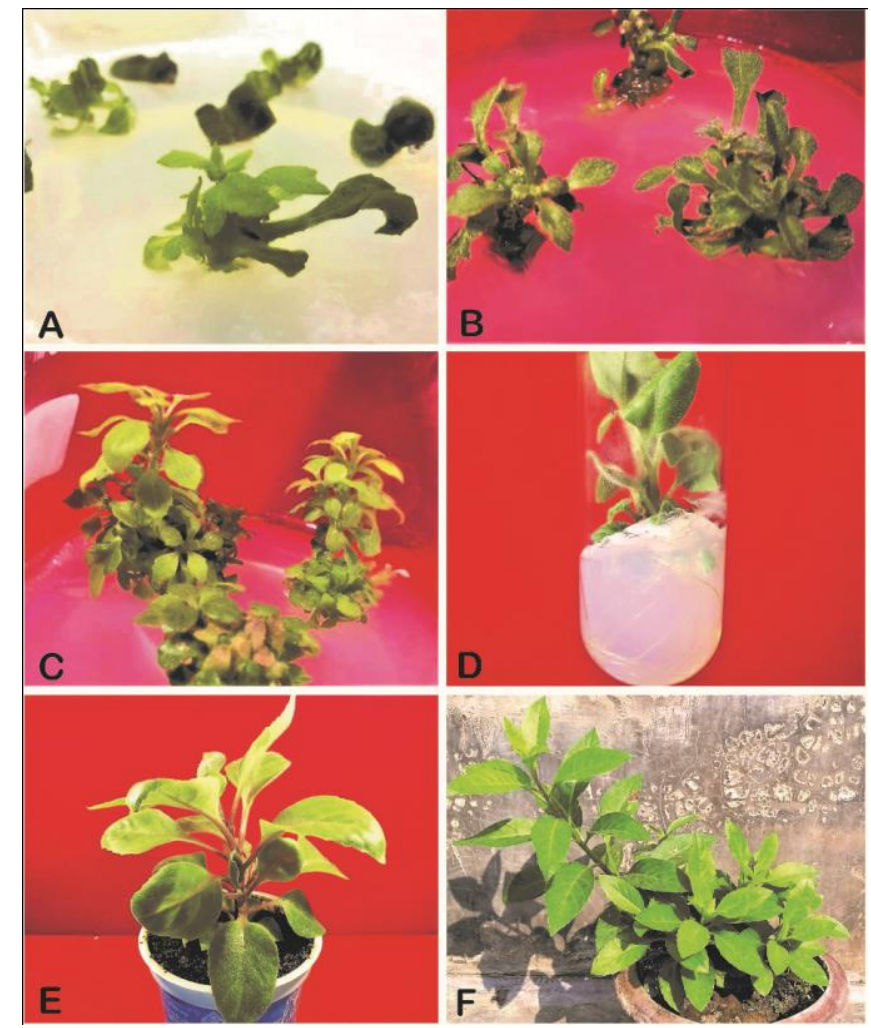

Figure 2. A-F: In vitro regeneration of plantlet from leaf explants of Gynura procumbens.

A: Proliferation of adventitious shoots from leaf explantscultured on MS medium containing 4.0 $\mu$ M BAP with $2.0 \mu M$ NAA after five weeks of culture incubation.

$\boldsymbol{B}-\boldsymbol{C}$ : Proliferation and development of multiple shoots from leaf segments on MS medium containing $4.0 \mu M$ BAP plus 2.0 $\mu M$ NAA after eight weeks of culture.

D: Formation of roots from the regenerated shoots cultured on MS medium supplemented with $4.0 \mu M$ IBA.

$\boldsymbol{E}-\boldsymbol{F}$ : Growth of transplant on the vermiculite after 6 weeks $(E)$ and twelve weeksof transfer under ex vitro conditions $(F)$.

\section{Effects of Sucrose Concentrations}

Shoot development from excised leaf may vary among species and genotypes upon the level of optimum sucrose concentration (Nowak et al., 2004). The percentage of shoot formation, average number and length of shoots per culture increase gradually with the increase of the sucrose concentration in medium up to $30 \mathrm{gm} / \mathrm{l}$. However, the performance of shoot development gradually decreased with an increase in the sucrose concentration to above $30 \mathrm{gm} / \mathrm{l}$. The medium with $30 \mathrm{gm} / 1$ sucrose showed the highest percentage of shoot formation $(92.31 \%)$, average number of shoots per culture $(20.1 \pm 0.2)$ and average length of shoots per culture $(6.7 \pm 0.8 \mathrm{~cm})$ (Fig. 4). An efficient carbon sources for enhanced shoot growth and development has been examined in tissue cultures of some plant species, such as Echinacea purpurea (Nilanthai and Yang, 2013), Allium chinense (Xu et al., 2008), Elaeocarpus robustus (Rahman et al., 2004) and Paederia foetida (Amin et al., 2003). Our study revealed that MS medium with $30 \mathrm{gm} / \mathrm{l}$ sucrose showed the best result for shoot formation in $G$. porcambens. Lower concentrations of sucrose have been shown to be less effective for shoot formation. On the other hand, the detrimental effect of a high sucrose concentration on shoot formation implies that the osmotic level in the medium may be inhibitory to further shoot development. Thus, high concentrations of sucrose seem to inhibit shoot growth and development. This observation are supported by another report (Nowak et al., 2004). 
In Vitro Propagation and Ex Vitro Establishment of a Medicinal Plant- Gynura procumbens (Lour.) Merr. through Leaf Culture

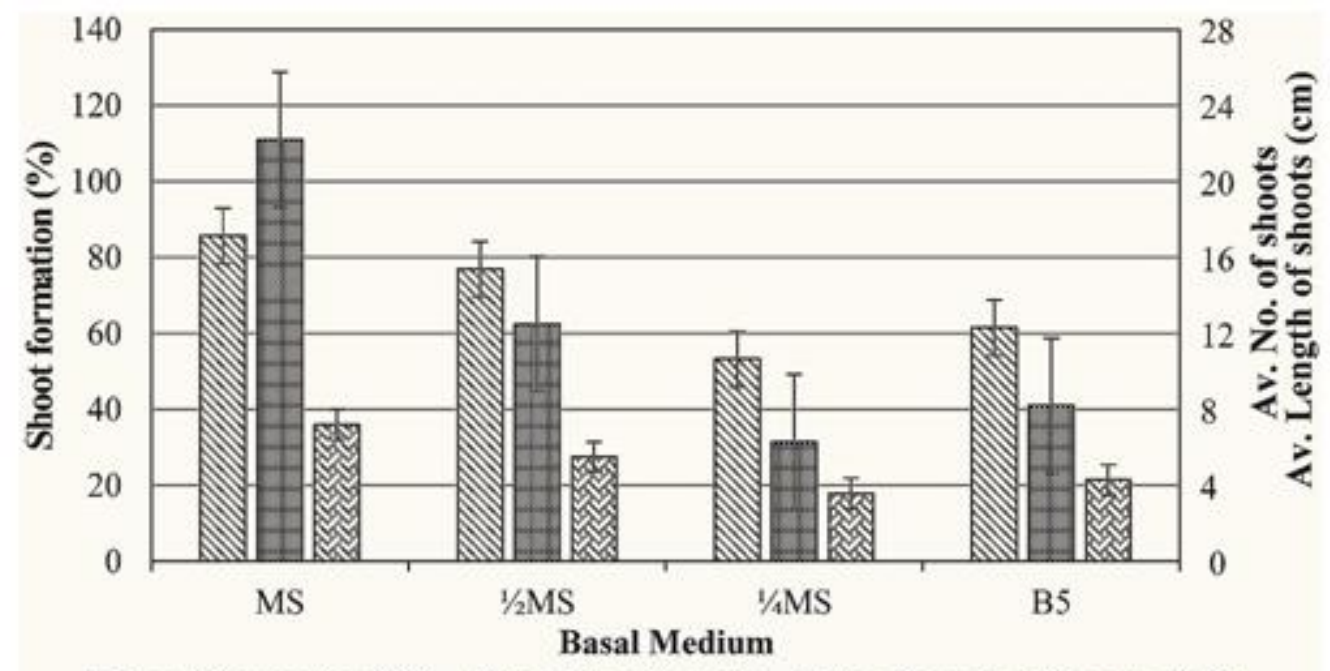

QShoot formation (\%) Av. No. of shoots $\triangle$ Av. Length of shoots (cm)

Figure 3. Effects of different basal media containing $4.0 \mu M$ BAP with $2.0 \mu M$ NAA on in vitro shoot multiplication from leaf explants of Gynura procumbens.

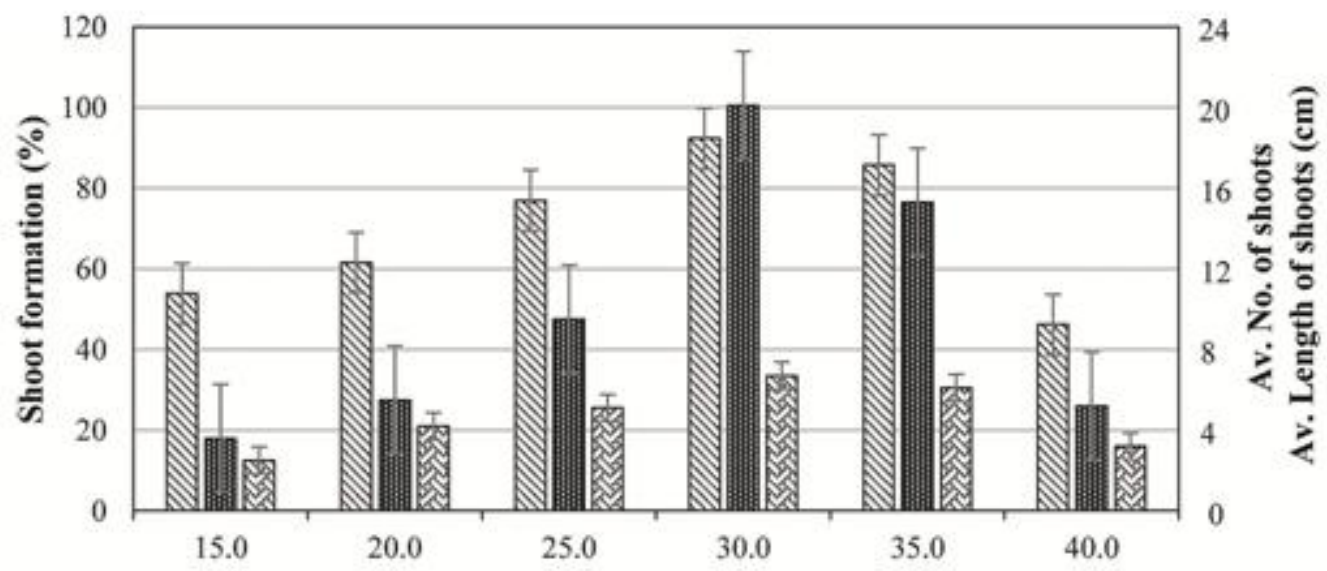

Sucrose Concentration (g)

$\mathbb{S}$ Shoot formation (\%) 国 Av. No. of shoots $₫$ Av. Length of shoots (cm)

Figure 4. Effects of sucrose concentrations on adventitious shoot proliferation from leaf segments on MS medium containing $4.0 \mu \mathrm{M}$ BAP plus $2.0 \mu \mathrm{M}$ NAA of Gynura procumbens.

\section{Effects of $p H$}

In vitro multiple shoot development depends upon some other factors rather than plant growth regulators. The $\mathrm{pH}$ of culture medium is an important factor for the in vitro proliferation and healthy culture growth. Leaf segments taken from in vitro culture that grew on medium containing $4.0 \mu \mathrm{M}$ BAP with $2.0 \mu \mathrm{M}$ NAA were used in the present study. Leaf segments were cultured on MS medium adjusted to five different levels of $\mathrm{pH}$ viz. 5.0, 5.5, 6.0 and 6.5 but supplemented with only one concentration of cytokinin ( $4.0 \mu \mathrm{M}$ BAP). Among these $\mathrm{pH}$ levels, the highest percentage of explant showing proliferation was observed on the media adjusted to $\mathrm{pH} 6.0$.and that was $84.62 \%$.The second highest percentage of explant showing proliferation was observed on media having $5.5 \mathrm{pH}$ and it was $76.92 \%$. The lowest frequency of explant showing proliferation was observed on the media where $\mathrm{pH}$ was adjusted to 5.0 where the proliferation frequency ranged from $46.15 \%$ (Fig. 5). Average number of usable shoot per culture was highest in medium having $\mathrm{pH} 6.0$ and the value was $18.3 \pm 0.5$. From the present investigation it was revealed that both lower (5.0) and higher (6.5) $\mathrm{pH}$ levels hindered multiple shoot proliferation. Comparatively less acidic $\mathrm{pH}$ (6.5) gave harder gel which might have adverse effects on regeneration and proliferation of shoots. In vitro proliferation of Azadirachta indica (Gautam et al., 1993), Plantago ovata (Barna and Walklu,1988) and Smilax zeylanica (Jha et al., 1987) shoots were increased significantly when the $\mathrm{pH}$ the culture media was adjusted at 5.8 before autoclaving. 
In Vitro Propagation and Ex Vitro Establishment of a Medicinal Plant- Gynura procumbens (Lour.) Merr. through Leaf Culture

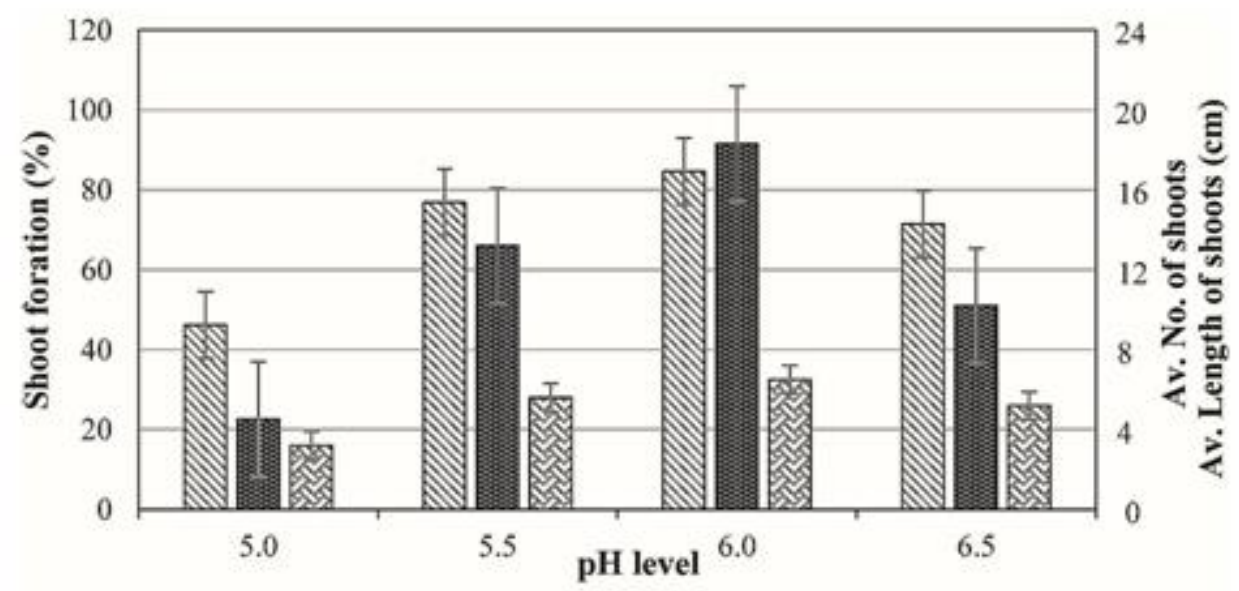

$\mathbb{Q}$ Shoot formation (\%) Av. No. of shoots $\mathrm{Av}$. Length of shoots (cm)

Figure 5. Effects of pH level on adventitious shoot proliferation from leaf segments on MS medium containing 4.0 $\mathrm{\mu M}$ BAP plus 2.0 $\mu$ M NAA of Gynura procumbens.

\section{Rooting}

Root formation was enhanced considerably when either IBA, NAA or IAA at different concentrations were added to MS medium. IBA supplemented medium remarkably influenced the rate of root induction than NAA or IAA (Fig. 6). Among the different concentrations of IBA tested, highest frequency $(92.31 \%)$ with maximum average number $5.2 \pm 0.2$ of roots per shoot and longest $6.3 \pm 0.3$ $\mathrm{cm}$ roots having considerable lateral roots were obtained with $4.0 \mu \mathrm{M}$ IBA (Fig. 2D) whereas, $4.0 \mu \mathrm{M}$ NAA produced considerable root formation where highest frequency was 76.92, average number of roots $4.3 \pm 0.3$, and average length of roots $4.5 \pm 0.5 \mathrm{~cm}$. On the other hand IAA was found to be less effective than IBA or NAA regarding rooting of micro-shoots where the roots were thin in nature. Poor rooting was observed when micro-shoots $(2-4 \mathrm{~cm}$ in length) were cultured on auxin free MS medium (data not shown). In this study, IBA was proved to be best auxin as comparable to NAA or IAA with regard to all rooting parameters. There are many authors reported that IBA has been found suitable for rooting in many species like Gynura porcambens (Majumder et al., 2016), Acacia nilotica (Dhabhai et al., 2010), Bauhinia variegata (Mathur and Mukunthakumar, 1996), Phellodendron amurense (Azad et. al., 2005, 2009), and Pterocarpus marsupium (Husain et al., 2008).

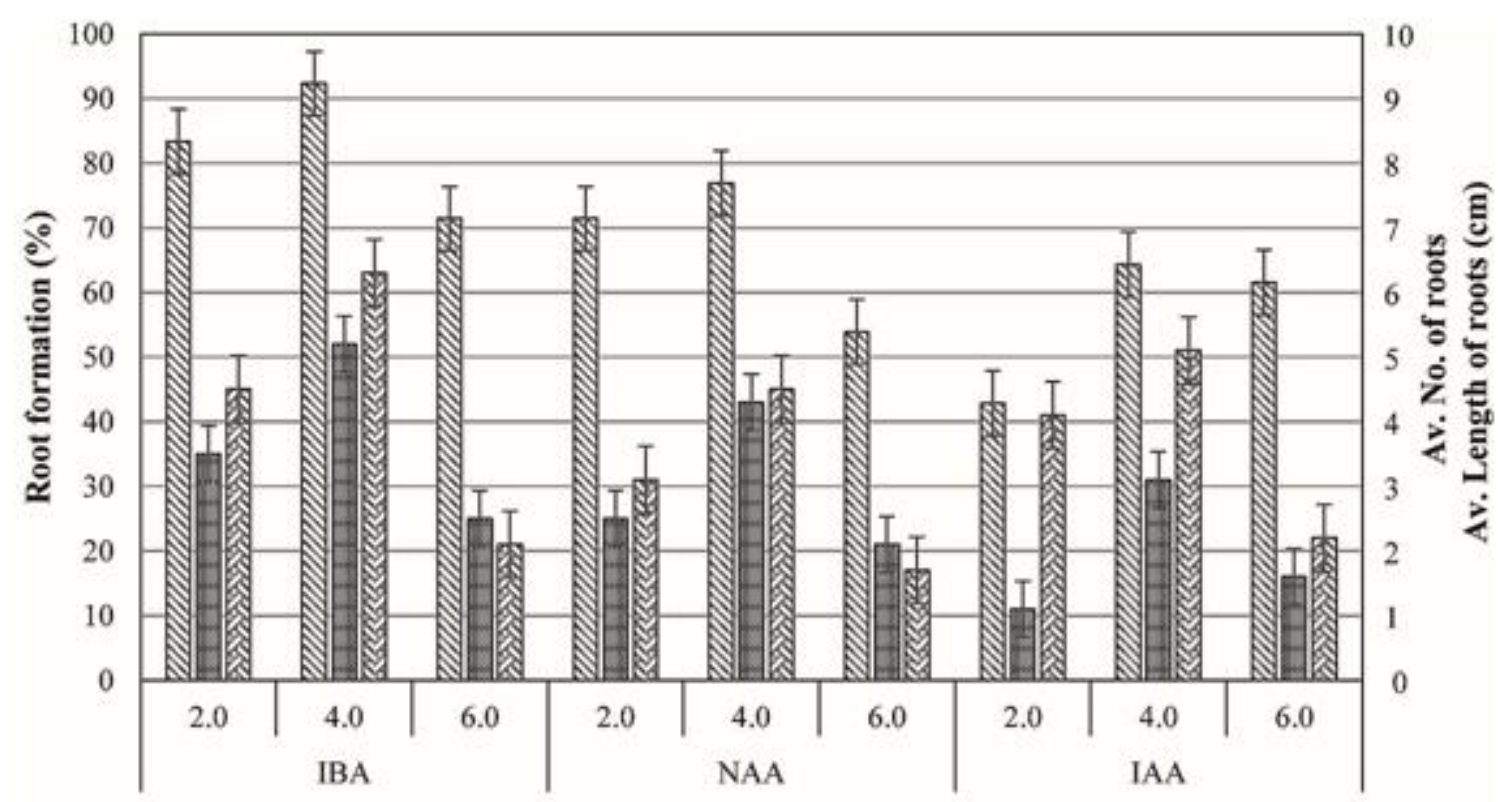

$\mathbb{Q}$ Root formation (\%) $\quad$ Av. No. of roots $\quad$ Av. Length of roots (cm)

Figure 6. Effects of auxins on adventitious rooting on MS medium of in vitro derived micro-shoots of Gynura procumbens. 
In Vitro Propagation and Ex Vitro Establishment of a Medicinal Plant- Gynura procumbens (Lour.) Merr. through Leaf Culture

\section{Hardening and Acclimatization}

After successful rooting of micro-shoots, attempts were taken to establish regenerated plantlets onto soil. Plantlets had been transferred to small plastic pots containing soil mix (garden soil: compost: sand, 2:1:1) and Vermicompost separately, maintained under humid ex vitro condition in the growth room (Fig. 2E). The in vitro derived plantlets acclimated better under ex vitro condition when they were maintained in growth room for 20 days before transferring them to outdoor condition (Fig. $2 \mathrm{~F}$ ). Finally, 95\% transplanted plantlets were survived and acclimated well under ex vitro condition after 25 days of transplantation.

The results revealed that survival rate, plant height, and number of leaf of plantlets after 20 days of transplantation were significantly influenced by vermicompost and soil mix (Fig. 7). Mean survival rate $100 \%$, plant height $7.2 \mathrm{~cm}$ and number of leaves 15.4 in vermicompost were significantly greater than that of soil mix where survival rate, plant height, number of leaves were $85.7 \%, 4.5 \mathrm{~cm}$, and 10.2, respectively. These agreements were supported in Lycopersicum esculentum (Azarmi et al., 2008; Joshi et al., 2010; Goel and Kaur, 2012), Stevia (Zaman et al., 2015), Phaseolus vulgaris (Singh et al., 2011), Solanum lycopersicum (Vaidyanathan and Vijayalakshmi, 2017).

These studies showed that increases of plant growth at vermicompost in the potting medium could probably be due to improvement in the physico-chemical properties of the container medium, increase in enzymatic activity, increases in microbial diversity and activity, nutritional factors and plant growth regulators (Atiyeh et al., 2000a,b; Arancon et al., 2004a,b). Results obtained from this experiment revealed that growth parameters such as survival rate, plant height number of leaf were significantly affected by applying vermicompost. Azarmiet al. (2008) reported positive effects of vermicompost on the growth and yield in tomato, especially increases flower blossom, shape and weight of fruits. Mishra et al. (2005) showed that vermicompost had beneficial effects on growth and yield of rice, especially caused significant increase of many growth parameters, seeds germination, chlorophyll concentration and yield. Similar results were reported by Najar et al. (2015), who mentioned that brinjal (Solanum melongena) plant growth and yields in field soils amended with compost were significantly greater than those in the untreated plots.

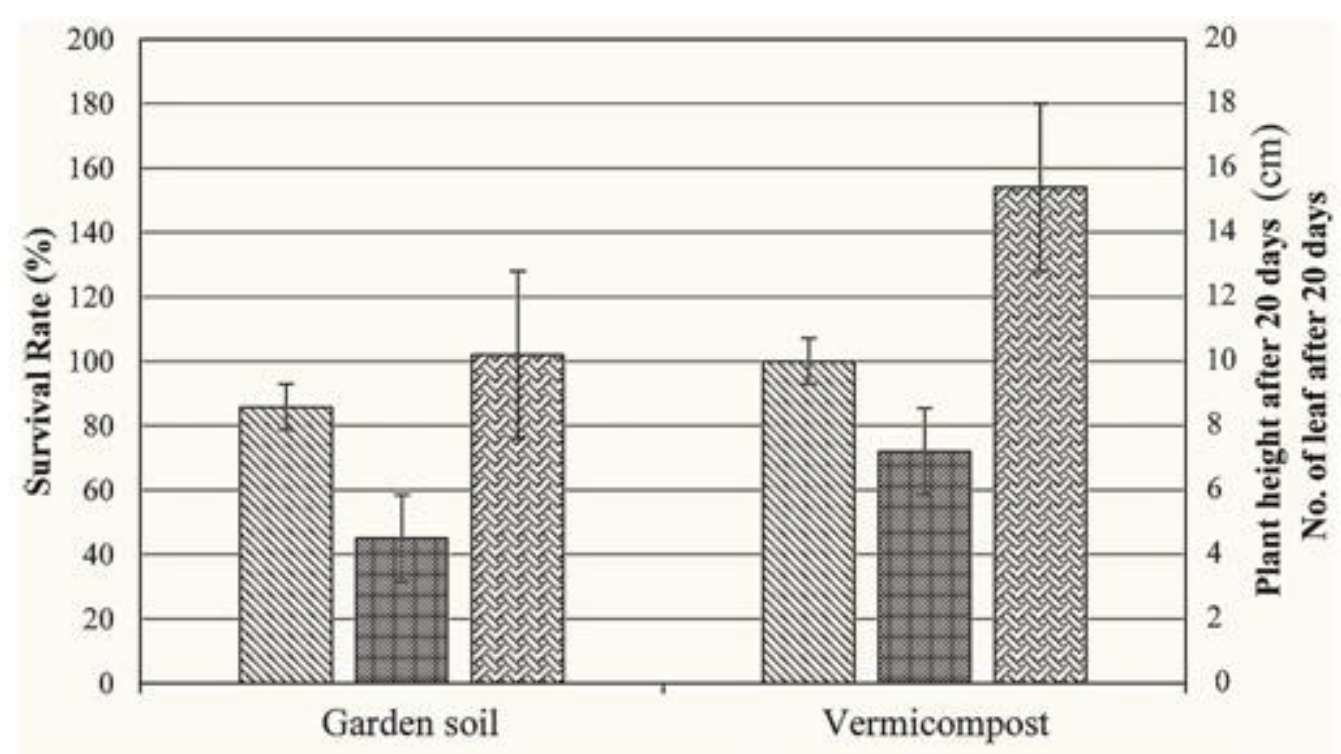

$\triangle$ Survival rate $(\%)$ Plant height after 20 days $₫$ No. of leaf after 20 days

Figure 7. Effects of vermicompost and soil mix for acclimatization of in vitro derived plantlets of Gynura procumbens under ex vitro condition.

\section{CONCLuSiONS}

Traditionally, G. procumbens leaves have been known to possess high medicinal values and was used to treat illnesses such as eruptive fevers, rash, kidney diseases, migraines, constipation, hypertension, cancer and diabetes mellitus. Our observation indicates that due to the lack of knowledge, nursery owners are not interested to grow seedlings of these non-conventional plants. The method of 
production of G. probumbens is not popular. So, that the people are not using these commercially important plants sustainably. Thus, the Biodiversity is being damaged and the G. procumbens plant users and businesspersons are being in difficulties for their need. The sustainable use and the rapid production are badly needed. The conventional multiplication method is not sufficient for plantation program. Then multiplication through modern technique is urgently required. Tissue Culture technique in the proposed project is to develop a protocol for producing a large number of disease free plants in a short period irrespective of seasonal variations. These plants will be used for developing ex situ conservation, cultivation, and nursery development at home garden. Rapid propagation of $G$. procumbens plants through tissue culture and other conventional method will ensure the availability of disease free plantlets throughout the country. Moreover the tissue culture derived plantlet are easy to transfer from place to place.

\section{ACKNOWLEDGEMENT}

This work was finically supported by the Institute of Biological Sciences, Rajshahi University, Bangladesh (No. A-1214-5/52/RU/Life \& Earth-03/16-17/64). The authors also like to thank their colleagues from the Department of Botany, University of Rajshahi for their constant assistance and cooperation.

\section{REFERENCES}

Abbas, H., Qaiser, M., and Naqvt, A.B. (2010). Rapid in vitro multiplication of Accaia nilotica subsp. hemisperica, a critically endangered endemic taxon. Pak. J. Bot., 42(6):4087-4093.

Akowuah, G.A., Amirin, S., Mariam, A., and Aminah, I. (2001). Blood sugar lowering activity of Gynura procumbens leaf extracts. J. Trop. Med. Plant., 2: 5-10.

Algariri, K., Atangwho, I. J., Meng, K. Y., Asmawi, M. Z., Sadikun, A., andMurugaiyah, V. (2014). Antihyperglycaemic and toxicological evaluations of extract and fractions of Gynura procumbens leaves. Trop. Life. Sci. Res.,25: 75-93.

Amin, M.N., Rahman, M.M., and Manik, M.S. (2003). In vitro clonal propagation of Paederia foetida L. A medicinal plant of Bangladesh. Plant Tiss. Cult., 13: 117-123.

Arancon, N.Q., Edwards, C.A., Atiyeh, R.M. and Metzger, T.D. (2004). Effect of vermicomposts produced from food waste on the growth and yields of greenhouse peppers. Bioresour. Technol., 93:139-144.

Atiyeh, R.M., Arancon, N., Edwards, C.A. and Metzger, J.D. (2000a). Influence of Earthworm-processed pig manure on the growth and yield of greenhouse tomatoes. Bioresour. Technol., 75: 175-180.

Atiyeh, R.M., Dominguez, J., Sulber, S. and Edwards, C.A. (2000b). Change in biochemical properties of cow manure during processing by earthworms (Eisenia andrei. Bouche) and the effects on seedling growth. Pedobiologia., 44: 709-724.

Azad, M.A.K., Amin, M.N. and Begum, F. (2003). Rapid clonal propagation of a medicinal plant - Adhatoda vasica Nees. using tissue culture technique. OnLine J. Biol. Sci.,3 (2): 172-182.

Azad, M.A.K., Yokota, S., Ohkubo, T., Andoh, Y., Yahara, S. and Yoshizawa, N. (2005). In vitro regeneration of the medicinal woody plant Phellodendron amurense Rupr. through excised leaves. Plant Cell, Tissue and Organ Cult., 80(1): 43-50.

Azad, M.A.K., Yokota, S., Yahara, S., and Yoshizawa, N. (2004). Effects of explant type and growth regulators on organogenesis in a medicinal tree, Phellodendron amurense Rupr. Asian J. Plant Sci., 3(4): 522-528.

Azarmi, R., Ziveh, P.S., and Satari, M.R. (2008). Effect of Vermicompost on Growth, Yield and Nutrition Status of Tomato (Lycopersicum esculentum). Pakistan J. Biol. Sci., 11: 1797-1802.

Bacchetta, L., Remotti, P. C., Bernardini, C. and Saccardo, F. (2003). Adventitious shoot regeneration from leaf explants and stem nodes of Lilium. Plant Cell, Tissue and Organ Cult., 74: 37-44.

Barna, K.S. and Walklu, A.K. (1988). Axillary shoot induction and plant regeneration in Plantago ovata Forssk. Plant Cell, Tissue and Organ Cult., 15: 169-173.

Bohari, M., Pauliena, S., Muhajir, H., Khozirah, S. andLajis, N. (2006). Glucose uptake: stimulatory Activity of Gynura procumbens in 3T3- F442A adipocytes. In: Malaysian Medicinal Plant: Chemistry and Biological Activity. UNIMAS and Malaysian Natural Products Society, Sarawak.

Dhabhai, K., Sharma, M.M., and Batra, A. (2010). In vitro clonal propagation of Acacia nilotica (L.)-a nitrogen fixing tree. Researcher., 2(3):7-11.

Gamborg, O. L., Miller, R. A., and Ojima, K., (1968) Nutrient requirements of suspension cultures of soybean root cells. Exp. Cell Res., 50: 151-158. 
In Vitro Propagation and Ex Vitro Establishment of a Medicinal Plant- Gynura procumbens (Lour.) Merr. through Leaf Culture

Gautam, V.K., Nanda, K. and Gupta, S.C. (1993). Development of shoots and roots in anther-derived callus of Azadirachta indica A. Juss: A medicinal tree. Plant Cell. Tissue and Organ Cult., 34: 13-18.

Goel, S. and Kaur, N. (2012). Impact of Vermicompost on Growth, Yield and Quality of Tomato Plant (Lycopersicum esculentum). J. Adv. Lab. Res. Biol., III: 218-284.

Hamid, M., Saufi, M., and Nik, M.M. (2004). Study on antidiabetic properties of Gynura procumbens Merr, in 18 Seminar of the Malaysian Natural Products Society (Kota Kinabalu: Universiti Malaysia Sabah).

Hassan Z, Yam MF, Ahmad M, Yusof APM (2010).Antidiabetic properties and mechanism of action of Gynura procumbens water extract in streptozotocin-induced diabetic rats. Molecules 15:9008-9023

Hegazi, G.A.E., and Gabr, M.F. (2010). Overcoming early shoot senescence of Colutea istria Miller propagated in vitro. J Am Sci., 6(12):1733-1738.

Husain, M.K., Anis, M., and Shahzad, A. (2008). In vitro propagation of a multipurpose leguminous tree (Pterocarpus marsupium Roxb.) using nodal explants. Acta. Physiol. Plant., 30:353-359.

Iskander, M.N., Song, Y., Coupar, I.M., and Jiratchariyakul, W, (2004). Antiinflammatory screening of the medicinal plant Gynura procumbens. Plant Food Hum. Nutr., 57(3-4): 233-244.

Jha, S., Gupta, J.S. and Sen, S. (1987). Tissue culture of Smilax zeylanica L. Acta Hortic., 208: 273-279.

Jin,W., Wang, Y., and Wang, H. (2014). Adventitious shoot regeneration from leaves of apple rootstock 'Pingyitiancha' (Malus hupehensis var. pinyiensis) and genetic fidelity of regenerated plantlets using SSR markers. Can. J. Plant Sci., 94: 1345-1354 doi:10.4141/CJPS2013-357.

Jiratchariyakul, W., Jarikasem, S., Siritantikorn, S., Somanabandhu, A., Frahm, A.W. (2000). Antiherpes Simplex Viral Compounds from Gynura procumbens Merr. Mahidol University Annual Res. Abstracts., 28:182.

Joshi, R. and Vig, A.P. (2010).Effect of Vermicompost on Growth, Yield and Quality of Tomato (Lycopersicum esculentum L). African J. Basic and Applied Sci., 2 (3-4): 117-123.

Kanchanapoom, K., Buntin, N. and Kanchanapoom, K. (2009). Micropropagation through adventitious shoot regeneration from leaf culture of Torenia fournieri Lind. Songklanakarin J. Sci. Technol., 31 (6): 587-590.

Karatas, M., Aasim, M., Çinar, A., and Dogan, M. (2013). Adventitious Shoot Regeneration from Leaf Explant of Dwarf Hygro (Hygrophila polysperma (Roxb.) T. Anderson). The ScientificWorld J. Vol. P. 1-7. http://dx.doi.org/10.1155/2013/680425.

Kaur, K., Verma, B., and Kant, U. (1998). Plants obtained from the khair tree (Acacia catechu Willd.) using mature nodal explants. Plant Cell Rep., 17:421-429

Lee, H.W.,Hakim, P.,Rabu, A. andSani, H.A. (2012). AntidiabeticeffectofGynura procumbensleavesextracts involvemodulationof hepaticcarbohydratemetabolisminstreptozotocin-induceddiabeticrats. Journal of MedicinalPlantsRes., 6(5):796-812.

Majumder, S., Biswas. A., and Rahman, M. M. (2016): In vitro mass propagation of Gynura procumbens (lour.) Merr. - an important medicinal plant. Asian J. Natural \& Applied Sci., 5(3): 71-79.

Mathur, J., and Mukunthakumar, S. (1996). Micropropagation of Bauhinia veriegata and Parkensonia aculeata from nodal explants of mature trees. Plant Cell, Tissue and Organ Cult., 28:169-175.

Mishra, M.S., Rajani, K., Sahu-Sanjat, K. and Padhy-Rabindra, N. (2005). Effect of vermicomposted municipal solid wastes on growth, yield and heavy metal contents of rice (Oryza sativa). Fresenius Environ. Bull., 14: 584-590.

Murashige, T. and Skoog, F. (1962) A revised medium for rapid growth and bioassays with tobacco tissue cultures. Physiol. Plant., 15: 473-497.

Najar, I.A. and Khan, A.B. (2015). Effect of macrophyte vermicompost on growth and productivity of brinjal (Solanum melongena) under field conditions. Int J. Recycl Org. Waste Agricult., 4:73-83.

Nilanthi, D., and Yang, Y. (2013) In vitro induction of octaploid from colchicine-treated tetraploid petiole explants of Purple Coneflower (Echinacea purpurea L.). Tropical Agril. Res.Extn., 16.

Nowak, B., Miczynski, K., and Hudy, L. (2004). Sugar uptake and utilization during adventitious bud differentiation on in vitro leaf explant of Wegierka Zwykla plum (Prumus domestica). Plant Cell, Tissue and Organ Cult., 76: 255-260.

Rahman, M.M., Amin, M.N., and Ahmed, R. (2004). In vitro rapid regeneration from cotyledon explant of native olive (Elaeocarpus robustus Roxb.). Asian J. Plant Sci., 3: 31-35.

Singh, B.K., Pathak, K.A., Verme, A.K., Verma, V.K. and Deka, B.C. (2011). Effects of vermicompost, fertilizer and mulch on plant growth, nodulation and pod yield of French bean (Phaseolus vulgaris 1.). Vegetable Crops Res. Bull., 74: 153-165.

Thangavel, P., Britto, S.J. and Senthilkumar S.R. (2011). Adventitious shoot regeneration from leaf explants of 
In Vitro Propagation and Ex Vitro Establishment of a Medicinal Plant- Gynura procumbens (Lour.) Merr. through Leaf Culture

the valuable medicinal herb Plectranthus barbatus Andrews. African J. Biotec., 10(43): 8562-8569.

Vaidyanathan, G. and Vijayalakshmi, A. (2017). Effect of vermicompost on growth and yield of tomato. European J. Pharma. and Medical Res., 4: 653-656.

Wanmei, J, Yuanhua, W., and Hua, W. (2014). Adventitious shoot regeneration from leaves of apple rootstock 'Pingyitiancha' (Malus hupehensis var. pinyiensis) and genetic fidelity of regenerated plantlets using SSR markers. Can. J. Plant Sci., 94: 1345-1354.

Xu, Z., Um, Y. C., Kim, C. H., Lu, G., Guo, D. P., Liu, H. L., Bah, A. A. and Mao, A. (2008). Effect of plant growth regulators, temperature and sucrose on shoot proliferation from the stem disc of Chinese jiaotou (Allium chinense) and in vitro bulblet formation. Acta. Physiol. Plant., 30:521-528.

Zaman, M.M., Chowdhury, M.A.H., Islam, M.R.and Uddin, M.R. (2015). Effects of vermicompost on growth and leaf biomass yield of stevia and post-harvest fertility status of soil. J. Bangladesh Agril. Univ., 13(2): $169-174$

Zhang, X.F. and Tan B.K. (2000).Effects of an ethanolic extract of Gynura procumbens on serum glucose, cholesterol and triglyceride levels in normal and streptozotocin-induced diabetic rats. Singapore Med J., 41 (1):9-13.

Citation: M. A. K. Azad, M. N. Amin., "In Vitro Propagation and Ex Vitro Establishment of a Medicinal Plant- Gynura procumbens (Lour.) Merr. through Leaf Culture", International Journal of Advanced Research in Botany, vol. 4, no. 1, p. 19-28, 2018. http://dx.doi.org/10.20431/2455-4316.0401004

Copyright: (C) 2018 Authors. This is an open-access article distributed under the terms of the Creative Commons Attribution License, which permits unrestricted use, distribution, and reproduction in any medium, provided the original author and source are credited. 